\title{
An Empirical Study on the Driving Factors of Customer Value of Fashion Apparel Enterprises Zhejiang Province
}

\author{
Wu Zhixin Dr./ associate professor \\ Associate Dean of Business Administration College \\ Zhejiang University of Finance \& Economics Dongfang College \\ No. 2nd, Yangshan Road, Haining Town, Zhejiang, China 314408
}

\begin{abstract}
Fashion is always a theme, a trend and also the focus of apparel enterprises competition. It increases the intensity of competition in the apparel market. The customer value is the source to obtain sustainable competitive advantage source for fashion apparel enterprises. Based on the discussion of customer value theory, this paper uses the methods of factor analysis, case investigation and interview to analyze the driving factors of customer value of garment enterprises in Zhejiang province. The key factors are quality, function, price and brand according to the degree of importance. This paper provides reference to create customer value for garment enterprises and enhance the competitiveness of enterprises.
\end{abstract}

Keywords-Fashion apparel enterprises; Customer value; Driving factors; Factor analysis

\section{INTRODUCTION}

With the rapid development of China's economy and the improvement of people's material living standard, more and more people, especially the young people are in the pursuit of fashion and trends. Customer demand is constantly changing. What kind of clothing the enterprises provide to the customers better than competitors? How clothing enterprises will take the lead in grasping the dynamic change of customer value, changing mode, adjusting structure, innovating thinking, improving their market share and core competitiveness will become the focus of garment enterprises.

\section{A REVIEW OF RELATED THEORIES ABOUT CUSTOMER PARTICIPATION AND CUSTOMER VALUE}

\section{A. Review of Customer Value Theory}

The concept of customer value was first proposed by foreign scholars in the 1980s. In the study of customer valuerelated theory, the Scholars ' definition of customer value is different. Through literature search, the research on customer value mainly has the following representative viewpoints:

(1) Zeithaml (2004) [1] He analyzed customer value from the perspective of perceived value. He argues that customer value is a comprehensive evaluation of what the customer can perceive as a trade-off between the benefits it has to pay and the costs it pays [1].
(2) Jantrania (1994) He studies customer value from the perspective of relationship marketing or relationship value. He believes that the dimensions of relational value include economic dimensions, strategic dimensions and behavioral dimensions [2].

(3) Payne and Frow (1997) he studies customer value from the perspective of lifelong value. They believe that customer value refers to the valuable results that are produced when delivering superior customer value. Yang Weiwei thinks that customer value refers to the evaluation and tradeoff between the product attributes, effects, and the total cost of the products that were perceived by the customer as a whole in a particular scenario [3].

To sum up, for the elaboration of customer value concept, one (take Zeithaml as the representative) is to emphasize "dualistic theory" view, namely they all regard customer value as "get" and "lose" two kinds of factor weigh and compare. This is the process of static contrast. The other (represented by Jantrania) while affirming that value is the result of trade-offs and emphasizes that trade-offs are a dynamic development process. The comparative elements are diverse, including product attributes, product effectiveness, and three levels of usage results.

\section{B. The Driving Factors of Customer Value}

Customer value drivers are factors that influence customer value and form its source. For the study of customer value driving factors, different scholars hold different opinions, there are mainly three kinds:

(1) The customer value driver based on single factor. Albrecht (2014) believes that customer value is the perception that a customer is satisfied with a particular demand. That is, customer value is perceived as a perception, and the driving factor is quality [4].

(2) Customer value drivers based on two factors. The driving factor of customer value, Higgins, is that customers get benefits and costs.

(3) Customer value driven factors based on multiple factors Higgins (2008) believes that the driving factors of customer value mainly consist of product quality, service quality and price factor [5]. 


\section{Research and Design of the Driving Factors of Customer Value}

This paper sorts out the theory of customer value. Combined with the relevant literatures of customer value theory and using PZB's SERVQUAL research method and Woodruff's customer value system. This paper follows the principle of practicality, feasibility and comparability to interview the Zhejiang Province specializes in fashion brand apparel enterprises such as Eral Group, Zhejiang Semir Garment Co., Ltd, Zhejiang Taisilk Costumes Co., Ltd. After the revision of the relevant experts and professors, it concludes that there are 10 customer value drivers for the competitiveness of apparel enterprises. There are (I) clothing texture;(2) style design;(3) Price/performance ratio;(4) Fashion elements;(5) Professional level of marketing personnel;(6) Marketing Personnel service attitude;(7) The convenience of sales outlets;(8) Brand awareness;(9) Brand reputation;(10) The integrity of the company.

\section{QUESTIONNAIRE DESIGN}

This research questionnaire method is the direct investigation method, mainly uses the 7 Component table of Likert to investigate the fashion brand clothing purchaser's attitude. 1 points is completely unimportant, 7 points is absolutely important, others in turn. The questionnaire is divided into two parts, the first part is the introduction, the main description. The second part is the survey of the importance of each factor by the visitors.

\section{A. Sample and Data Collection}

In order to ensure the validity and reliability of the data, the data survey method of this research questionnaire is not random sampling. Through the distribution of questionnaires in Zhejiang Province the author takes 150 of customers to do the importance of evaluation. Because of the purchase of fashion clothing are mostly young women, so the study is limited to the age of 18-45-year-old young female friends. The writer recovers of 142 questionnaires, of which 118 effective questionnaires. Recovery efficiency is $94.67 \%$ and $78.66 \%$. Therefore, the number of questionnaires reaches the requirements of the sample size standard.

\section{B. Test of Reliability and Validity}

Reliability and validity, also known as dependability and validity, are mainly to effectively analyze and verify the stability and reliability of each index in the scale. Generally, the Cronbach Alzha coefficient is used to test the validity. The Cronbach Alzha coefficient is between 0.8-1, which indicates the stability and reliability of the scale. An acceptable range between 0.65-0.7. In this paper, the SPSS17.0 software is used to deal with the collected data, the Cronbach Alzha coefficient of this questionnaire is measured to be 0.806 , which indicates that the questionnaire has high consistency and reliability. Based on a large number of literatures and related theories the validity of questionnaire is better through in-depth interviews and expert revisions, combined with the data from the customer interview.

\section{Factor Analysis}

Factor analysis is to represent most of the information of the original interrelated variables by using a few independent factors from many customer value drivers. In the study, the KMO Index and Bartlett spherical test were used to determine whether the questionnaire was suitable for factor analysis. By using SPSSL7. 0 statistic software Gets the following results: The KMO index is 0.725 . It shows that there is no significant difference in correlation between the variables. The square value of the Bartlett spherical test is from the table L know that only the value of the anterior umbrella factor is greater than 1 , and the cumulative variance contribution rate of the first 3 factors reaches $90.83 \%$, so it plays a very good role in interpreting. According to the gravel chart, the table of the first 3 factors are higher, the tables are greater than L, and the tables of the following factors are less than 1 , generally we think that the factor has enough explanatory power when the table is greater than 1. Therefore, it is more appropriate to extract the first 3 factors. Principal component Analysis Rotation method: With the Kaiser standard orthogonal rotation method from the composition score covariance matrix of table 2, the main component analysis of the 3 factors are completely independent of each other to meet the requirements of factor analysis.

TABLE I. TOTAL VARIANCE OF INTERPRETATION

\begin{tabular}{|c|c|c|c|c|c|c|c|c|c|}
\hline \multirow{2}{*}{$\begin{array}{c}\text { Compone } \\
\text { nts }\end{array}$} & \multicolumn{3}{|c|}{ Initial eigenvalue } & \multicolumn{3}{|c|}{ Extract squared sum } & \multicolumn{3}{|c|}{ Rotation squared } \\
\hline & Total & $\begin{array}{c}\% \text { of } \\
\text { variance }\end{array}$ & Cumulative\% & Total & $\begin{array}{c}\% \text { of } \\
\text { variance }\end{array}$ & Cumulative\% & Total & $\begin{array}{c}\% \text { of } \\
\text { variance }\end{array}$ & Cumulative\% \\
\hline 1 & 8.787 & 43.85 & 43.85 & 8.787 & 43.85 & 43.85 & 9.078 & 45.31 & 45.31 \\
\hline 2 & 6.886 & 34.37 & 78.22 & 6.886 & 34.37 & 78.22 & 6.128 & 30.59 & 75.9 \\
\hline 3 & 2.527 & 12.61 & 90.83 & 2.527 & 12.61 & 90.83 & 2.308 & 11.51 & 87.41 \\
\hline 4 & 0.876 & 4.37 & 95.2 & & & & & & \\
\hline 5 & 0.578 & 2.88 & 98.08 & & & & & & \\
\hline 6 & 0.138 & 0.688 & 98.768 & & & & & & \\
\hline 7 & 0.089 & 0.444 & 99.212 & & & & & & \\
\hline 8 & 0.078 & 0.389 & 99.601 & & & & & & \\
\hline 9 & 0.067 & 0.334 & 99.935 & & & & & & \\
\hline 10 & 0.009 & 0.065 & 100.00 & & & & & & \\
\hline
\end{tabular}


According to table 1 rotational component matrix results can be explained as follows: the first category of factors including (I) clothing texture;(2) style design;(3) Price/performance ratio;(4) Fashion elements, so that the 4 factors named product quality and price. The second type of factor includes (5) the Professional level of marketing personnel; (6) Marketing Personnel service attitude; (7) The convenience of sales outlets. These 3 factors describe the various services that are accepted in the shopping and consumption process. Therefore, the name is quality of service. The third kind of factors include (8) brand awareness; (9) Brand reputation; (10) The integrity of the company, these 3 factors describe the company's brand value and the company's integrity image, so it is named brand and image.

TABLE II. ROTATIONAL COMPONENT MATRIX

\begin{tabular}{|c|c|c|c|}
\hline & \multicolumn{2}{|c|}{ Components } \\
\cline { 2 - 4 } & 1 & 2 & -0.0011 \\
\hline (I)Clothing texture & 0.012 & 0.878 & 0.0078 \\
\hline (2)Style design & 0.011 & 0.788 & -0.068 \\
\hline (3)Cost-effective & 0.052 & 0.785 & 0.0012 \\
\hline $\begin{array}{c}\text { (4)Fashion elements } \\
\text { (5)Professional level of } \\
\text { marketing personnel }\end{array}$ & -0.001 & 0.875 & 0.778 \\
\hline $\begin{array}{c}\text { (6)Marketing Staff Service } \\
\text { Attitude }\end{array}$ & 0.002 & 0.0026 & 0.808 \\
\hline $\begin{array}{c}\text { (7) Convenience of sales } \\
\text { outlets }\end{array}$ & -0.016 & -0.0012 & 0.816 \\
\hline (8)Brand awareness & 0.0013 & -0.0012 & 0.016 \\
\hline (9)Brand reputation & 0.811 & -0.0078 & -0.012 \\
\hline $\begin{array}{c}\text { (10)The integrity of the } \\
\text { company }\end{array}$ & 0.852 & -0.0068 & -0.023 \\
\hline
\end{tabular}

Extraction Method: Principal Component Analysis method Rotation method: Orthogonal rotation method with Kaiser standardization

A: The rotation converges after 5 iterations.

\section{CONCLUSION}

Through the carding of related literatures and the extension of relevant research results this paper uses the method of questionnaire to designs and analyzes the driving factors which affect the customer value of fashion brand apparel enterprise, according to the result of factor analysis. It is concluded that the customer value that affects the competitiveness of such enterprises is directly driven by 3 factors. According to its the important degree are: brand and image, product quality and price, service quality. Consumers in the process of purchasing clothing is the most concerned about the brand and image. This point is validated in the Eral Group Company, Zhejiang Semir Garment Co., Ltd, Zhejiang Taisilk Costumes Co., Ltd. more than 10 apparel enterprises, marketing staff, research and development designers, senior leaders and other in-depth interviews were, Today young women are not putting special concern on the price and function of clothing (such as service life, products, etc.), in response to this, Eral Group Company put forward the "Salute to fashion" business mission. The pursuit of fashion as the company's most important business philosophy. Each year in the design of fashion style investment in a large number of human, material and financial resources. Of course, these efforts are also the majority of young female consumers trust which is the Eral Group Company based on customer value driven by one of the strategic objectives. In addition, the brand represents consumers ' feelings of trust in products and services. Product quality and price/performance is one of the important factors that affect consumer purchase. This is related to the ultimate interest of consumers, clothing enterprises to obtain competitive advantage must implement the differentiated strategy of products and services, such as increasing online and offline customer experience, improve innovation ability, in meeting customer needs. In order to continuously improve the competitiveness of apparel enterprises.

\section{REFERENCES}

[1] Zeitham V, Consumer Perceptions of Price,Quality and Value: 2004 (July): 2-22.

[2] Wilson D.T.Jantrania SA. Understanding the Valueofa Relation shila Asia-Australia Marketing Journal.1994,2 (1): 55-66.

[3] PayneK,P.Frow.Relationship Markefing: Key Issuesfor the Utilities Sector. Journal of Marketing Management, 1997, (13): 463-477.

[4] Albrecht K. Customer Value [J]. Executive Excellence, September 2014.

[5] Higgins K.T.The Value of Customer Value Analysi. Marketing. Research.2008.(10). 